Article

\title{
Comparative Hagiology and/as Manuscript Studies: Method and Materiality
}

\author{
Barbara Zimbalist
}

Department of English, The University of Texas at El Paso, 500 University Ave, El Paso, TX 79968-0526, USA; bezimbalist@utep.edu

Received: 11 October 2019; Accepted: 28 October 2019; Published: 31 October 2019

\begin{abstract}
Although the academic study of hagiography continues to flourish, the role of comparative methods within the study of sanctity and the saints remains underutilized. Similarly, while much valuable work on saints and sanctity relies on materialist methodologies, issues of critical bibliography particular to the study of hagiography have not received the theoretical attention they deserve. This essay takes up these two underattended approaches to argue for a comparative materialist approach to hagiography. Through a short case study of the Latin Vita of Lutgard of Aywières (1182-1246) written by the Dominican friar Thomas of Cantimpré (c. 1200-1270), I suggest that comparative material research into the textual history of hagiographic literature can provide us with a more comprehensive and nuanced picture of the production of any specific holy figure, as well as the evolving discourses of sanctity and holiness in general. While this suggestion emerges from my own work on medieval hagiography from the Christian Latin West, it resonates with recent arguments by Sara Ritchey and David DiValerio to call for a materially comparative approach to narratives of holy lives in any religious tradition in any time period. Furthermore, I suggest that medieval studies, and in particular medieval manuscript studies, may have much to offer to scholars of sanctity working in later periods and other settings. Offering a view of material textual scholarship as intrinsically comparative, we may expand our theoretical definitions of the comparative and its possibilities within the study of sanctity.
\end{abstract}

Keywords: comparative literature; comparative method; comparative religions; critical bibliography; hagiography; hagiology; manuscript studies; medieval Christianity; religious studies; sainthood

In the century between Canon MacCulloch's proposal of "comparative hagiology" as a discrete field of study and Massimo Rondolino's call for its serious reconsideration, the study of hagiography has developed into an academic discipline on its own terms. ${ }^{1}$ Countless serious and theoretically ambitious studies now provide more scholarly bibliography than any single graduate seminar could include. $^{2}$ Book series from American and European publishers encourage new theoretical approaches to hagiography while calling for expanded attention to global traditions of sanctity. ${ }^{3}$ Yet the role and force of the comparative within the study of hagiography remains-with a few exceptions-curiously undertheorized, despite the flourishing fields of comparative religions, comparative literatures, and their attendant professional organizations. ${ }^{4}$ Many possible reasons for this particular lacuna exist,

See (MacCulloch 1908; Rondolino 2017).

See, for example, (Brown 1981; Vauchez 1981; Heffernan 1988; Head 1990; Kleinberg 1992, 2008; Bartlett 2013).

For new book series, see Amsterdam University Press' Hagiography beyond Tradition and Routledge's Sanctity in Global Perspective.

4 For comparative studies in religion see, for example, (Clooney 2010; Clooney and Stosch 2018; Freiberger 2018, 2019; Freidenreich 2004); and in general the "Comparative Religion" series from Oxford University Press; see as well the 
from the place of hagiographic scholarship within studies in religion and literature, more broadly to the difficulties inherent in academic approaches to the sacred. Yet, as Todd French notes in this issue, while the disciplinary restrictions inherent to academic specialization create a difficult terrain for comparative approaches to religious topics, they nevertheless "render collaborative work imperative." In what follows, I want to focus on a specialized but nevertheless crucial facet of hagiography: the unique challenges inherent within the critical bibliography of hagiographic literature. ${ }^{6}$ I am mindful as well, here, of the historical, conceptual, and disciplinary issues raised by the term "hagiography", long used as a generic classification with colonialist, patriarchal, and Christo-centric associations. ${ }^{7}$ I have chosen to use the term "hagiography" in the discussion that follows-with some caution-because I focus specifically on a methodology for approaching the literature of sanctity: the textual record of the life stories of holy men and women. ${ }^{8}$ In this relatively narrow terminological usage I depart from Sara Ritchey's and Massimo Rondolino's use of the term, explained elsewhere in this issue, to describe a much wider range of medial and conceptual records of the sacred imaginary, which variously combine in the production of holy identity and reputation. I agree with my co-contributors that hagiography in and of itself exceeds the textual, and I am mindful in particular of Jon Keune's caution here, that we give careful nuance to the various media expressing sanctity, since "the word hagiography cannot but prioritize textuality in its very restricted sense of written documents. ${ }^{\prime 9}$ However, for the purposes of this essay focused on materialist approaches to the literature of sanctity, I have chosen to use the older term hagiography for this very reason, because, in Ritchey's formulation, "the graphia or text-production of the hagiographical process concentrates the hagio of the exemplary figure". The material history of hagiographic texts- the various texts that lie behind the official or canonical versions of any saint's life story in any tradition-demand rigorous and context-specific approaches to the oral and written narratives of their sanctity because it is those narratives that preserve and even-through the multiple configurations charted here by David DiValerio—create sanctity itself. ${ }^{10}$ A materialist approach to those narratives thus necessitates the technical methodology of manuscript studies and book history.

While the study of any particular saint, hagiography, or hagiographic tradition may at first glance appear singular, monolingual, or culturally isolated, in actual fact, the differences in cultural context between literary and spiritual traditions demands nuanced scholarly engagement with the complex balances of religious, political, and social forces that generate the cultural milieux of holiness. ${ }^{11}$ Indeed, as Massimo Rondolino argues elsewhere in this issue, the term "hagiography" itself signifies "an analytical category for the taxonomy of sources that contribute to construct and promote the recognition of a given individual as a perfected being in the context of a particular religious theory of truth." 12 The textual history of any single hagiographic text often encompasses a long and complicated history of narrative negotiation among speakers, languages, and versions of a life story, more often than not resulting in the type of generic diversity of sources discussed here by DiValerio, and able

Comparative Studies in Religion Unit of the American Academy of Religion. For studies in literature, see the rise in comparative literature departments in American universities since the 1990s, journals such as Comparative Literature (Duke University Press), book series such as Harvard Studies in Comparative Literature (Harvard University Press), and the ongoing work of the American Comparative Literature Association.

5 French explains, "our particular scholarly communities ... are ill-practiced at—and perhaps ill-equipped for—crossing over traditions in the interest of interdisciplinary perspectives and compelling theories that might expand our ways of knowing." (French 2019).

6 For foundational theoretical discussion of critical bibliography see (Chartier 1994; Febvre and Martin 1976; among others); for introduction to medieval manuscript studies see (Clemens and Graham 2007; Johnston and Dussen 2015); for examples of influential materialist readings of texts in manuscript that offer new views of a particular subject, author, corpus, or reading culture, see (Dagenais 1994; Bahr 2013; Lifshitz 2014).

7 See in particular the essays by Keune, Ritchey, DiValerio, and Rondolino in this issue.

8 (Ritchey 2019; Rondolino 2019).

(Keune 2019).

10 For excellent studies of hagiographic manuscript culture see (Kuefler 2014; Bcheiry 2018).

11 For sanctity and holiness as communally constructed, see the essential work of (Brown 1981; Delooz 1962; Heffernan 1988; Kleinberg 1992); see also Rondolino in this issue.

12 (Rondolino 2019). 
to reveal a holy imaginary along more indexical axes, as Ritchey suggests, than we might expect. ${ }^{13}$ I suggest further that attention to the material history of the literature of sanctity-to the religious literature that Western scholarship has long termed hagiography-allows us to ask questions that reveal a comparative approach to hagiography from the inside out. What is the role of material history, manuscript studies, and print history in comparative studies in religious literature, and in particular in studies of hagiography? Can questions of critical bibliography be comparative? Or, to ask in another way, can such questions be anything but comparative? Self-reflective interrogation of the material history of hagiographic literature may be closer to Keune's "comparative-prioritized" method than we realize, able to "disrupt normative readings" as French recommends, precisely because our narratives of the textual, material history of hagiographic literature remain largely unexamined-and unquestioned. ${ }^{14}$ Only through a comparative approach to the material record can we begin to ask such questions and work toward a more nuanced understanding of the literature of sanctity.

In what follows, I offer one set of perspectives on these issues by way of reflections on a brief case study. The text I will discuss-the Vita of Lutgard of Aywières (1182-1246 CE), written in the mid-thirteenth century by the Dominican friar Thomas of Cantimpré (1200-1270 CE) - appears to exemplify the authoritative textual singularity attributed to high-medieval Latin hagiography in the Western Christian tradition. ${ }^{5}$ This singularity, often imagined as textual, linguistic, and authorial, receives reinforcement through inclusion within the official canon of the Bollandist Acta Sanctorum, which offers a definitive, authoritative text of a saint's life. As David DiValerio and Jon Keune observe in their essays here, comparative methodology appears to cohere uneasily with the apparently singular normativity of the textual, materialist orientation of hagiographic literature: the holy life story of a saintly person, assumed to be written by an authoritative, male, clerical author, most likely in service of canonization efforts. ${ }^{16}$ The textual history of Lutgard's Vita, however, tells an entirely different story of narrative collaboration, textual variants, differing translations, and ongoing editorial intervention. It reveals this apparently singular Vita to be the product of multiple, sometimes competing forces, and demonstrates that only a comprehensive, comparative view of this diverse plurality can begin to show us the history of Lutgard, her sanctity, and her Vita. In its particulars, Lutgard's Vita demonstrates one of the main reasons that comparative methodologies have had such small purchase in what otherwise remains the flourishing scholarly field of hagiography. Simply put, the official, printed version of Lutgard's Vita in the Acta Sanctorum canonizes the text at the same time that it obscures its own varied and diverse material history. ${ }^{17}$ Through a comparative approach to the narratives and manuscripts of Lutgard's Vita, however, we might not only recover some of that history and gain new perspective on the diverse influences that collude in the production of sanctity, but we can also trace the contours of a materialist methodology that argues for a more internally comparative approach to hagiography. ${ }^{18}$ Although comparative scholarship remains most frequently conceptualized as comparative across or between traditions, languages, and cultures, comparison within any apparently singular tradition of religious literature-comparison of the various literary, conceptual, and ideological forces that collude in the production of sanctity-offers valuable new insight both into the production of the hagiographic text as well as the production of sanctity itself. ${ }^{19}$ While approaches such as Ritchey's analytical index or DiValerio's formal vocabulary reveal narrative plurality within perceived

13 (DiValerio 2019; Ritchey 2019).

14 (Keune 2019; French 2019).

5 Lutgard's Vita has been edited and published in Latin by the Bollandists (Bolland 1897) and in English translation as part of Thomas of Cantimpré's oeuvre (Newman 2008).

16 On hagiographic scholarship as essentially comparative, see (Rondolino 2017, 2019). In Rondolino's estimation hagiography not only essentially functions comparatively but also invites—even necessitates-reflection on that methodological quality.

17 On this point, see DiValerio's discussion of how the reworking of hagiographic materials renders earlier sources invisible (DiValerio 2019).

18 See note 14 .

19 See note 11 . 
textual singularity, comparison of the different actors (human and/or object) within the material history of a single text further reveal the multiplicity inherent within apparently singular traditions. The act of comparison, when considered as a fundamental aspect of a materialist approach to holy lives, thus invites theoretical reflection on the comparative possibilities inherent within studies of hagiography writ large: as method, concept, and discipline.

As I explain above, my choice to discuss Lutgard's Vita stems from the vast differences between the canonical version of her Vita as recorded in the Acta Sanctorum and the material record of that text before its "official" Bollandist printing. I am inspired in this textual focus by Sara Ritchey's work on late-medieval hagiographic manuscripts, particularly her observation that "the fundamental mobility of medieval texts ... signified in ever-changing ways during the process of transmission." 20 Precisely because of its material variety and variance, that is, medieval hagiography often offers a particularly rich opportunity for a comparative material approach. ${ }^{21}$ A Cistercian prioress and mystic, Lutgard remains somewhat well known within circles of Catholic devotion as the patroness of the blind and disabled, a founding figure of the devotion to the Sacred Heart of Jesus, and an unofficial patron saint of Flanders. Her Vita is thought to have been composed within two years after her death by her spiritual friend and confessor Thomas of Cantimpré, a Dominican friar who had previously written vitae of Marie d'Oignies, Christina Mirabilis, and Margaret d'Ypres. ${ }^{22}$ While the Vita was very likely intended to promote Lutgard's canonization, she was never formally canonized; she remained popular locally, however, and a cult in her honor flourished for centuries after her death. While now little studied, Lutgard's Vita was much admired, often translated, and frequently recopied by medieval copyists and compilers, who saw her as one of the mulieres religiosae of high medieval Liège whose spirituality offered new modes of devotion and piety to high medieval women. ${ }^{23}$

Lutgard's Latin Vita circulated in ten manuscripts, one of them (Brussel, Koninglijke Bibliotheek 7919) significantly shorter than the other nine. Dutch scholars have long debated the relationship between different manuscript versions of the Latin Vita. Guido Hendrix has termed the shorter version of the Vita the "primitive vita" or Vita Antiqua. ${ }^{24} \mathrm{He}$ argued that the Bollandists who had first edited the text had erroneously rejected the shorter version for invalid reasons-which included, in his view, a mistaken view of the shorter Vita as an abridgment rather than an original or early draft of the Vita. His comparative reading raised serious questions about the Vita's authorship and reception. If the shorter version was indeed a true Vita Antiqua, he argued, than Thomas of Cantimpré must either have composed the Vita in parts over time; or the longer version of the Vita represented a collection of material written by a later author. This may not seem like a dramatic claim; yet when considered through the lens of generic scholarship, the argument takes on more urgent force. Lutgard's Vita has long been regarded as Thomas of Cantimpré's masterpiece. To accept Hendrix's argument would mean accepting the possibility that Thomas' final and greatest work might not have been either of those things; and more profoundly, it would mean accepting a view of hagiographic authorship as collaborative and communal. As many scholars have long argued, sanctity is essentially a communal construct, yet extending this communal impulse to the act of authorship remains a less enthusiastically embraced approach to the material history of hagiography. ${ }^{25}$ A comparative reading of a single vita's versions, however, suggests a communal mode of authorship more accurately reflecting the ways in which hagiography constructs its subject over time.

Since Hendrix's argument, however, scholarship continued to treat the Vita as the product of a single author; finally, in 1996 Jean-Baptiste Le Fèbvre published a rebuttal of Hendrix, claiming that

20 (Ritchey 2017, p. 1103).

21 I share Ritchey's view of medieval textual transmission grounded in Paul Zumthor's concept of mouvance and Bernard Cerquiglini's concept of variance (Zumthor 1989; Cerquiglini 1999).

22 For Thomas' complete oeuvre, see (Newman 2008); for recent analysis of his work as a whole see (Smith 2019).

23 For discussion of Lutgard's piety see (Bynum 1987; Smith 2019).

24 (Hendrix 1978).

25 (Kleinberg 1992; Vauchez 1981; Heffernan 1988). 
the Vita Antiqua was not in fact an early draft but rather a later abridgment-as the Bollandists had long ago supposed. ${ }^{26}$ Hendrix's challenge to the Bollandists' editorial practices was clearly unpopular, and Dutch scholarship has uniformly accepted the Acta Sanctorum version of the text and referenced Lefebvre as the authority on the manuscripts (not Hendrix). As a result, the canonical force of the Acta Sanctorum's editorial apparatus resists attempts at reexamination of the material history behind it. While on some level canonical persistence fuels the most fundamental goals of the Bollandist project in that it perpetuates a "stable" sanctity, that stability comes at the cost of a more nuanced understanding of the manuscript tradition of the vitae, of a clear view of the communal nature of that sanctity, and of precisely what Vitae such as Lutgard's continue to represent in academic settings. When we place the material history of the Latin Vita alongside a comparative reading of its vernacular translations, moreover, new possibilities for understanding the text and its authorship emerge.

Lutgard's Vita also circulated in manuscript in Dutch poetry, Dutch prose, and French prose. Each of these versions differs not only linguistically but formally from the canonical Latin Vita. The Dutch verse translation, the Leven Van Lutgart, preserved in Copenhagen Royal Library G.K.S. 168, consists of over 20,000 lines of poetry divided into stanzas of varying length, and an in-text dedication dates its composition before 1274 . For centuries, scholars attributed this translation to William van Affligem, though within the last fifty years this authorial attribution has become more contested. ${ }^{27}$ The thirteenth century manuscript translates only the second and third sections of the Latin Vita. Based on later references within the text to a lost first part, there is general consensus within Dutch scholarship that part one exited in verse translation at some point, though now lost, which makes the Copenhagen manuscript necessarily a copy of an earlier translated version of the Vita. The relatively early date suggests that translation of Lutgard's Vita was taken up almost immediately after her Latin Vita began to circulate, which has intriguing ramifications for the relationship of the two different Latin versions to each other. The two different prose translations support this view of temporal contiguity and complex Latin textual evolution.

The prose Dutch translation, preserved in a late fifteenth century manuscript at the Brussels Library of the Bollandists, consists only of the first fifteen chapters of the Latin Vita. In these details, the prose Dutch translation is most similar to the shorter version of the Latin Vita-the version Hendrix argued for as the Vita Antiqua. In a series of articles in the late 1970s and early 1980s, Hendrix claimed that the existence of the prose translation confirmed his suspicions that the shorter version of the Vita preceded the longer version, and thus that Thomas of Cantimpré composed Lutgard's life over a much longer period of time than generally accepted. The existence of this prose Dutch translation thus raises the possibility of an extended Latin translation informed by intermediate vernacular translation. This intriguing suggestion has yet to be taken up as a serious subject of study; furthermore, no earlier manuscript containing the prose translation is known to exist, which makes definitive knowledge of the relationship between the Latin Vita and the prose translation impossible. The same cannot be said, however, for the French prose translation, which represents a very early translation effort internally dated before $1248 .{ }^{28}$ Like the prose Dutch translation, it does not include the full Vita; like the verse Dutch translation, however, it does include material from the long Vita. Hendrix and Josef Van Mierlo suggested that it may represent a lost, intermediate Latin version of the Vita by Thomas, and thus provide evidence of a longer process of hagiographic authorship that may have incorporated originally vernacular material. ${ }^{29}$ This view of the vernacular translations, as potential contributors to the canonical Latin version of Lutgard's Vita, specifically challenges long-held views of Lutgard's

26 (Le Fèbvre 1996).

27 Currently, the dbnl considers the question of authorship "zeer onzeker", despite Erwin Mantingh's attempts to definitively prove William's authorship (Manitngh 2000).

28 The manuscript is preserved in a sixteenth century manuscript in the Leuven library of the faculty of Divinity; the prologue dedicates the text to Abbess Hadewijch of Aywières, who died in 1248.

29 (Hendrix 1978; Van Mierlo 1936). 
Vita as Thomas' magnum opus, and demonstrates the scholarly benefits of a comparative approach to material textual history.

I hope that the previous paragraphs have demonstrated in small part the revelatory power of a comparative approach to material history, by making visible how pervasive assumptions about Latin's anteriority and textual singularity might be usefully interrogated through a comparative, materialist approach. By accepting that vernacular translation may have played some role in the ongoing composition of Lutgard's canonical Latin Vita, we might take a new look at authorship as a communal venture that incorporated many more authorial participants than current scholarship allows. This type of materialist comparison, further, might combine productively with the analytical methods outlined here by DiValerio and Ritchey. Intersecting methodologies—and, often by extension, collaborative work, such as the work that inspired the essays in this issue-thus emerges as a valuable approach to the study of sanctity, despite its relative paucity in the critical record. In attempting to understand the pressures of canon and the workings of genre, we must always look to the material histories that sometimes obscure, sometimes reveal, but always shape those larger ideologies through which we encounter a text-ideologies which, as Rondolino and Keune point out, inform not just our approach to hagiographic subject but our very conception of hagiology, hagiography, and sanctity itself. Though I have focused here on a fairly conventional example of Western medieval Christian hagiography, I hope that these observations may inspire further reflection on any sanctity tradition, and on the academic discipline of hagiographic studies more broadly. Comparative investigation of the material history of hagiography_along with the collaborative, intersectional methodologies such investigation might inspire - can only augment our ideas about sanctity, authorship, and textuality, and allow us to chart new paths forward in our understanding of these discourses.

Funding: This research received no external funding.

Acknowledgments: This essay grew out of the presentations and workshops I attended at Trinity University in 2015, "European Religious Cultures Symposium" and 2017, “OLD BOOKS/ New Approaches", both organized by Andrew Kraebel; the 2016 Renaissance Society of America conference panel, "Religious Connectivity in Urban Communities (1400-1600)", organized by Sara Ritchey; and the "Comparative Hagiology: Issues in Theory and Method" workshop at the 2019 American Academy of Religion meeting, organized by Massimo Rondolino. I would like to thank Andrew, Sara, and Massimo, as well as the participants in those gatherings whose comments and insights inspired this continued work, including Alison Frazier, Mary Kate Hurley, Nancy Bradley Warren, Suzan Folkerts, and Jon Keune.

Conflicts of Interest: The author declares no conflicts of interest.

\section{References}

Bahr, Arthur. 2013. Fragments and Assemblages: Forming Compilations of Medieval London. Chicago: Chicago University Press.

Bartlett, Robert. 2013. Why Can the Dead Do Such Great Things? Saints and Worshippers from the Martyrs to the Reformation. Princeton: Princeton University Press.

Bcheiry, Iskandar. 2018. The Account of the Syriac Orthodox Patriarch Yühanun bar Say Allah (1483-1492): The Syriac Manuscript of Cambridge: DD.3.8(1). Gorgias Eastern Christian Studies 34. Piscataway: Gorgias Press.

Bolland, Jean. Ed. 1897. Vita Lutgardis Virgine in Aquiriae Brabantiai. In Acta Sanctorum. Paris: Palmé, pp. 189-210.

Brown, Peter. 1981. The Cult of the Saints. Its Rise and Function in Latin Christianity. Chicago: University of Chicago Press.

Bynum, Caroline. 1987. Holy Feast and Holy Fast: The Religious Significance of Food to Medieval Women. Berkeley: University of California Press.

Cerquiglini, Bernard. 1999. In Praise of the Variant: A Critical History of Philology. Translated by Betsey Wing. Baltimore: Johns Hopkins University Press.

Chartier, Roger. 1994. The Order of Books: Readers, Authors, and Libraries in Europe between the Fourteenth and Eighteenth Centuries. Translated by Lydia G. Cochrane. Stanford: Stanford University Press. 
Clemens, Raymond, and Timothy Graham. 2007. Introduction to Manuscript Studies. Ithaca: Cornell University Press.

Clooney, Francis X. 2010. Comparative Theology: Deep Learning Across Religious Borders. New York: Fordham University Press.

Clooney, Francis X., and Klaus Von Stosch, eds. 2018. How to Do Comparative Theology. New York: Fordham University Press.

Dagenais, John. 1994. The Ethics of Reading in Manuscript Culture: Glossing the "Libro de Buen Amor". Princeton: Princeton University Press.

Delooz, Pierre. 1962. Pour une Étude Sociologique de la Sainteté Canonisée dans l'Eglise Catolique. Archives de Sociologie des Religions 13: 17-43. [CrossRef]

DiValerio, David. 2019. A Preliminary Controlled Vocabulary for the Description of Hagiographic Texts. Religions 10: 585. [CrossRef]

Febvre, Lucien, and Henri-Jean Martin. 1976. The Coming of the Book: The Impact of Printing 1450-1800. Translated by David Gerard. New York: Verso.

Freiberger, Oliver. 2018. Elements of a Comparative Methodology in the Study of Religion. Religions 9: 38. [CrossRef]

Freiberger, Oliver. 2019. Considering Comparison. A Method for Religious Studies. New York: Oxford University Press.

Freidenreich, David M. 2004. Comparison in the History of Religions: Reflections and Critiques. Method E Theory in the Study of Religion 16: 80-101.

French, Todd. 2019. Saints across Traditions and Time Periods: Methods for Increasing Range and Reading in Comparative Frameworks. Religions 10: 577. [CrossRef]

Head, Thomas. 1990. Hagiography and the Cult of Saints. The Diocese of Orléans, 800-1200. Cambridge: Cambridge University Press.

Heffernan, Thomas. 1988. Sacred Biography. Saints and Their Biographers in the Middle Ages. Oxford: Oxford University Press.

Hendrix, Guido. 1978. Primitive versions of Thomas of Cantimpré's Vita Lutgardis. Citeaux 29: 153-206.

Johnston, Michael, and Michael Van Dussen, eds. 2015. The Medieval Manuscript Book: Cultural Approaches. Cambridge: Cambridge University Press.

Keune, Jon. 2019. Comparative vs. Hagiology. Two Variant Approaches to the Field. Religions 10: 575. [CrossRef]

Kleinberg, Aviad. 1992. Prophets in Their Own Country: Living Saints and the Making of Sainthood in the Later Middle Ages. Chicago: The University of Chicago Press.

Kleinberg, Aviad. 2008. Flesh Made Word: Saints' Stories and the Western Imagination. Translated by Jane Marie Todd. Cambridge: Harvard University Press.

Kuefler, Matthew. 2014. The Making and Unmaking of a Saint: Hagiography and Memory in the Cult of Gerald of Aurillac. Philadelphia: University of Pennsylvania Press.

Le Fèbvre, Jean-Baptiste. 1996. Sainte Lutgarde d'Aywières en son temps (1182-1246). Collectanea Cisterciensia 58 : 277-335.

Lifshitz, Felice. 2014. Religious Women in Early Carolingian Francia: A Study of Manuscript Transmission and Monastic Culture. The Bronx: Fordham University.

MacCulloch, Canon. 1908. Saintly Miracles: A Study in Comparative Hagiology. The Expository Times 19: 403-9. [CrossRef]

Manitngh, Erwin. 2000. Een monnik met een rol: Willem van Affligem, het Kopenhaagse Leven van Lutgart en de fictie van een meerdaagse voorlezing. Hilversum: Verloren.

Newman, Barbara, trans. and ed. 2008. Thomas of Cantimpré: The Collected Saints' Lives: Abbot John of Cantimpré, Christina the Astonishing, Margaret of Ypres, and Lutgard of Aywières. Turnhout: Brepols.

Ritchey, Sara. 2017. Saints' Lives as Efficacious Texts: Cistercian Monks, Religious Women, and Curative Reading, c. 1250-1330. Speculum 92: 1101-43. [CrossRef]

Ritchey, Sara. 2019. Dialogue and Destabilization: An Index for Comparative Global Exemplarity. Religions 10: 569. [CrossRef]

Rondolino, Massimo A. 2017. Cross-Cultural Perspectives on Hagiographical Strategies: A Comparative Study of the Standard Lives of St. Francis and Milarepa. Milton: Taylor and Francis. 
Rondolino, Massimo A. 2019. Some Foundational Considerations on Taxonomy: A Case for Hagiography. Religions 10: 538. [CrossRef]

Smith, Rachel. 2019. Excessive Saints: Gender, Narrative, and Theological Invention in Thomas of Cantimprés Mystical Hagiographies. New York: Columbia University Press.

Van Mierlo, Josef. 1936. Het leven van Sinte Lutgart oorspronkelijk Limburgsch? In Verslagen en mededelingen van de Koninklijke Vlaamse Academie voor Taal-en-Letturkunde. Gent: Drukkerij Erasmus, pp. 627-44.

Vauchez, André. 1981. La Sainteté en Occident aux Derniers Siècles du Moyen Âge d'après les Procès de Canonisation et les Documents Hagiographiques. Rome: École française de Rome.

Zumthor, Paul. 1989. Essai de poétique médiévale. Paris: Éditions du Seuil.

C 2019 by the author. Licensee MDPI, Basel, Switzerland. This article is an open access article distributed under the terms and conditions of the Creative Commons Attribution (CC BY) license (http://creativecommons.org/licenses/by/4.0/). 